\title{
Biochemical Characterization of the Indigenous Turkey (Meleagris Gallopavo) Populations in the Southern Guinea Savannah of Nigeria Using Blood Protein Markers
}

\author{
Ubu I $^{1 *}$, Momoh ${ }^{1}$, O. M. Ahemen ${ }^{1}$, T. Gambo D ${ }^{2}$, Ukwu O. $\mathrm{H}^{1}$
}

${ }^{1}$ Department of Animal Breeding and Physiology, College of Animal Science, University of Agriculture, Makurdi, Benue State, Nigeria

${ }^{2}$ Department of Animal Science, Faculty of Agriculture, Nasarawa State University Keffi, Nasarawa State, Nigeria

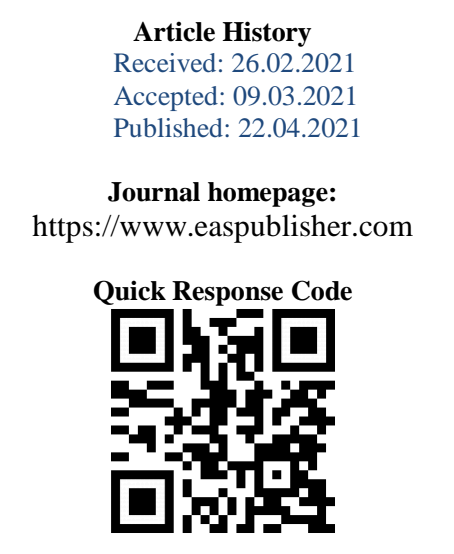

Article History

Abstract: This study was conducted to assess allelic and genotypic frequencies at the selected blood protein [Albumin (Alb.), Haemoglobin (Hb.) and Transferrin (Tf)] loci in indigenous turkey populations in Southern Guinea Savannah of Nigeria. Blood samples were collected from 42 birds, 14 birds each from Benue, Kogi and Nasarawa States via purposive sampling. The blood was analysed by electrophoresis. The genetic relationship of the population was determined by using Tools for Population Genetics Analysis (TFPGA), version 1.3. Result obtained indicated that, two co-dominant alleles (A and $\mathrm{B}$ ) which controlled three different genotypes (AA, $\mathrm{AB}$ and $\mathrm{BB}$ ) were observed for $\mathrm{Alb}$ and $\mathrm{Tf}$ while only two genotypes (AA and BB) for the Hb polymorphic loci were observed. Sexual differences in gene and genotypic frequencies of $\mathrm{Alb}, \mathrm{Hb}$ and $\mathrm{Tf}$ of male and female turkeys showed that genotype Alb ${ }^{\mathrm{AB}}$ and allele A were prevalent in the male while genotype Alb ${ }^{\mathrm{BB}}$ and Allele $\mathrm{B}$ were predominant in the female turkey. However, at the haemoglobin locus, genotype $\mathrm{Hb}^{\mathrm{AA}}$ and allele A were prevalent in the male and female turkey, respectively. For tranferrin, genotype $\mathrm{Tf}^{\mathrm{AB}}$ was most predominant in the male with equal frequencies in both alleles while genotype $\mathrm{Tf}^{\mathrm{BB}}$ and allele B were most prevalent in the female. From the estimates of variability parameters in the populations under study, it can be concluded that the populations are under similar evolutionary forces and there were no appreciable differences among them. It was recommended that the result of this study be used as initial guide for defining objective of genetic improvement and developing strategies for conservation of Nigerian indigenous turkey.

Keywords: Genetic variation, Heterozygosity, Haemoglobin, Indigenous turkeys, Polymorphism.

Copyright ( $\odot 2021$ The Author(s): This is an open-access article distributed under the terms of the Creative Commons Attribution 4.0 International License (CC BY-NC 4.0) which permits unrestricted use, distribution, and reproduction in any medium for non-commercial use provided the original author and source are credited.

\section{INTRODUCTION}

Nigeria has a high human population which is continuously on the increase. This increase has led to high demand for the available but insufficient animal and poultry products in the country. Poultry, particularly chickens are very important and have been recognized as important genetic resources among the avian species [1]. Poultry products are one of the cheapest and easily affordable animal protein sources for the teeming population. Turkeys are one of the most widely distributed of all poultry types in Nigeria [2]. Thus turkeys play very significant socio-cultural and economic roles in most African societies. Genetic diversities in the indigenous livestock species in developing countries are valuable attributes or assets for production, adaptation and resistance of the indigenous animals to endemic diseases. Many technologies including DNA based technology are employed in diversity studies.

Though DNA-based technologies are now the methods of choice for genetic characterization of livestock [3]; but its acceptance and application in Nigeria are limited primarily due to the myriad of challenges such as its high cost, lack of infrastructural facilities and dearth of trained experts. Nevertheless, recently, advances in the field of biotechnology has opened up new areas at molecular levels with the use of techniques, such as routine electrophoresis employed 
for the detection of polymorphism at protein and enzyme loci as well as other serological and immunogenetic procedures for measurement of variation [4]. Therefore, electrophoretic analysis of blood proteins and enzymes would be of immense contribution to the characterization of the indigenous turkey and would also provide insights into the genetic diversity existing among them. The objective of this study was to assess the level of genetic variation in the turkey populations through the estimation of allele numbers, allelic and genotypic frequencies at the selected blood protein (Albumin, Haemoglobin, Transferrin) loci.

\section{METHODOLOGY}

Location of the Study

The study was carried out at selected communities within three States: Benue, Nasarawa and Kogi in the southern guinea savannah agro-ecological zone of Nigeria. Southern guinea savannah lies on latitude $12^{\circ} \mathrm{N}$ and longitude $8^{\circ} \mathrm{E}$. The area has two distinct seasons, the wet season, which lasts from April to October and the dry season, which lasts from November to March. The annual rainfall ranges from 1000 to $2000 \mathrm{~mm}$ with temperature ranging from $6^{\circ} \mathrm{C}$ to $47^{\circ} \mathrm{C}$ (Google Maps, 2016).

\section{Experimental animals and their Management}

Forty two (42) adult indigenous turkeys consisting of 21 males and 21 females were used for this study. Fourteen (14) apparently healthy birds (7 males and females) each were randomly drawn from the three states of Benue, Nasarawa and Kogi. They were drawn from large random mating populations. The birds were reared primarily under traditional free range system by the owners; whereby birds scavenged for their feed and water with little or no supplementation.

\section{Blood sample collection}

About $4 \mathrm{ml}$ of whole blood was collected from the wing vein of each bird into correspondingly labelled heparinised tubes. Heparin was added to act as an anticoagulant, and blood contamination was prevented by using separate syringes and needles for individual bird. The samples were kept refrigerated for about 24 hours in ice packs and transported to the Animal Breeding and Genetics Laboratory of the Department of Animal Science, University of Ibadan, Ibadan, Oyo State, Nigeria for electrophoretic analysis.

\section{Laboratory Analysis}

The blood samples were centrifuged at $4^{\circ} \mathrm{C}$ for 20 minutes at 3000rmp in order to separate plasma and erythrocyte. The correspondingly labelled unheparinised tubes were used to determine Plasma. Erythrocytes were washed with drops of normal saline water and centrifuged again for 20 minutes at 3000rpm, and were then lysed with cold distilled water in order to release the haemoglobin. Then plasma and haemolysates aliquots were stored at $4^{\circ} \mathrm{c}$ prior to electrophoresis analysis. The lysed red blood cells were used to determined haemoglobin genotypes while plasma was used to detect albumin and transferrin genotypes.

\section{Electrophoretic Procedures}

Electrophoresis polymorphisms were performed for $\mathrm{Alb}, \mathrm{Hb}$ and $\mathrm{Tf}$ using cellulose acetate strip. Sampled were loaded on the well using separate syringe and needle and placed on the cellulose acetate paper by micro applicator then placed in the electrophoresis tank turning up and down on wetted filter paper across the supporters on the bridge from cathode to anode. Albumin was electrophoresed using Tris Citrate buffer $\mathrm{pH} 8, \mathrm{Hb}$ was electrophoresed using Tris Borate buffer $\mathrm{pH} 7.8$ and Transferrin was electrophoresed using Tris Glycine $\mathrm{pH} 6.8$ all at 150v for 30 minutes, respectively. After electrophoresis, each strip was stained for 30minutes using coomassie red and thereafter covered by distained solution $(5 \%$ acetic acid) until the bands were visible, air-dried and scored according to RIKEN [5] as adopted Akinyemi and Salako [6].

\section{Experimental Design and Statistical Analysis}

The design of the experiment was Completely Randomized Design (CRD). Stratified random sampling technique was employed in assembling the experimental bird's population. Seven females and males birds each were randomly sampled from each of the three states for blood protein analysis. Biochemical variability for blood protein (haemoglobin, transferrin and plasma albumin) was estimated using popgene statistical software version 1.31.

\section{RESULTS}

\section{Genotypic and Allelic Frequencies at the Selected Blood Protein Loci}

The genotypic frequencies of the three selected blood protein loci (Albumin, Haemoglobin and Transferrin) are presented in Table-1. Three distinct genotypes were observed at the albumin locus with $\mathrm{Alb}^{\mathrm{AB}}$ having the highest overall incidence. The frequency of $\mathrm{Alb}^{\mathrm{AB}}(0.500)$ was the same for Benue and Nasarawa populations. $\mathrm{Alb}^{\mathrm{AA}}$ and $\mathrm{Alb}^{\mathrm{BB}}$ had the same frequencies each for the Benue and Nasarawa poulations, respectively. For the Haemoglobin locus, only two genotypes; $\mathrm{AA}$ and $\mathrm{AB}$ were observed for all the three populations with $\mathrm{Hb}^{\mathrm{AA}}$ having the higher overall incidence for all the populations studied. $\mathrm{Hb}^{\mathrm{BB}}$ was not observed across the populations studied. At the Transferrin locus, three genotypes (Tf AA, AB, BB) were typed and $\mathrm{Tf}{ }^{\mathrm{AA}}$ was the most frequent genotype followed by $\mathrm{Tf}^{\mathrm{AB}}$ and $\mathrm{Tf}^{\mathrm{BB}}$ in that order. 
Table-1: Genotypic frequencies of three Blood protein loci in Nigerian Indigenous Turkey

\begin{tabular}{|l|l|l|l|l|l|}
\hline Locus & Genotype & $\begin{array}{l}\text { Benue } \\
(\mathbf{n = 1 4})\end{array}$ & $\begin{array}{l}\text { Kogi } \\
(\mathbf{n = 1 4})\end{array}$ & $\begin{array}{l}\text { Nasarawa } \\
(\mathbf{n = 1 4})\end{array}$ & $\begin{array}{l}\text { Overall } \\
(\mathbf{n = 4 2})\end{array}$ \\
\hline Albumin & AA & 0.143 & 0.286 & 0.143 & 0.191 \\
\hline & AB & 0.500 & 0.429 & 0.500 & 0.476 \\
\hline & BB & 0.357 & 0.286 & 0.357 & 0.333 \\
\hline Haemoglobin & AA & 0.714 & 0.500 & 0.571 & 0.595 \\
\hline & AB & 0.286 & 0.500 & 0.429 & 0.405 \\
\hline & BB & 0.000 & 0.000 & 0.000 & 0.000 \\
\hline Transferrin & AA & 0.286 & 0.214 & 0.357 & 0.286 \\
\hline & AB & 0.429 & 0.357 & 0.357 & 0.381 \\
\hline & BB & 0.286 & 0.429 & 0.286 & 0.334 \\
\hline n = Sample size & \multicolumn{5}{|l}{} \\
\hline
\end{tabular}

The allele frequencies of Albumin, Haemoglobin and Transferrin are presented in Table-2. Two alleles (A and B) were identified at all the loci. At the Albumin locus, allele B had similar abundance in Nasarawa and Benue populations, while in Kogi population both $\mathrm{A}$ and $\mathrm{B}$ alleles showed equal frequencies. On the whole, allele B was most abundant at the albumin locus. At the Haemoglobin locus allele B indicated prevalence. At the Transferrin locus, the frequency of A allele was the same with B in the Benue population, but they differed in the Nasarawa and Kogi populations. The $\mathrm{B}$ allele was most prevalent at the transferrin locus.

Table-2: Allelic Frequencies of three Blood Protein Loci in Nigeria Indigenous Turkey

\begin{tabular}{|l|l|l|l|l|l|}
\hline Locus & Genotype & $\begin{array}{l}\text { Benue } \\
(\mathbf{n = 1 4})\end{array}$ & $\begin{array}{l}\text { Kogi } \\
(\mathbf{n = 1 4})\end{array}$ & $\begin{array}{l}\text { Nasarawa } \\
(\mathbf{n = 1 4})\end{array}$ & $\begin{array}{l}\text { Overall } \\
(\mathbf{n = 4 2})\end{array}$ \\
\hline Albumin & $\mathrm{A}$ & 0.393 & 0.500 & 0.393 & 0.429 \\
\hline & $\mathrm{B}$ & 0.607 & 0.500 & 0.607 & 0.571 \\
\hline Haemoglobin & $\mathrm{A}$ & 0.857 & 0.750 & 0.786 & 0.798 \\
\hline & $\mathrm{A}$ & 0.143 & 0.250 & 0.214 & 0.202 \\
\hline Transferin & $\mathrm{A}$ & 0.500 & 0.393 & 0.536 & 0.476 \\
\hline & $\mathrm{A}$ & 0.500 & 0.697 & 0.464 & 0.524 \\
\hline $\mathrm{n}=$ Sample size \\
\hline
\end{tabular}

Sex Differences in Gene and Genotype Frequencies

Sexual differences in gene and genotypic frequencies of $\mathrm{Alb}, \mathrm{Hb}$ and $\mathrm{Tf}$ of male and female turkeys are presented in Table-3. At the Albumin locus three genotypes and two alleles were expressed in both sexes. Genotype $\mathrm{Alb}^{\mathrm{AB}}$ and allele $\mathrm{A}$ were prevalent in the male while genotype $\mathrm{Alb}^{\mathrm{BB}}$ and Allele $\mathrm{B}$ were predominant in the female. At the Haemoglobin locus, two alleles were observed in both sexes. Genotype $\mathrm{Hb}^{\mathrm{AA}}$ and allele $\mathrm{A}$ were prevalent in the male and female turkey, respectively. At the Transferrin locus, three genotypes and two alleles were expressed in both sexes. Genotype $\mathrm{Tf}^{\mathrm{AB}}$ was most predominant in the male with equal frequencies in both alleles while genotype $\mathrm{Tf}^{\mathrm{BB}}$ and allele $\mathrm{B}$ were most prevalent in the female.

Table-3: Gene and Genotypic Frequencies of three Blood Protein Makers in Adult Male and Female Nigerian Indigenous Turkey

\begin{tabular}{|c|c|c|c|c|c|}
\hline Locus & Sex & Genotype & Observed & Gene & Frequency \\
\hline \multirow[t]{6}{*}{ Albumin } & & AA & 0.278 & $\mathrm{~A}$ & 0.583 \\
\hline & Male & $\mathrm{AB}$ & 0.611 & B & 0.417 \\
\hline & & $\mathrm{BB}$ & 0.111 & & \\
\hline & & AA & 0.125 & $\mathrm{~A}$ & 0.312 \\
\hline & Female & $\mathrm{AB}$ & 0.375 & $\mathrm{~B}$ & 0.688 \\
\hline & & BB & 0.500 & & \\
\hline \multirow[t]{6}{*}{ Haemoglobin } & & AA & 0.611 & $\mathrm{~A}$ & 0.806 \\
\hline & Male & $\mathrm{AB}$ & 0.389 & $\mathrm{~B}$ & 0.194 \\
\hline & & $\mathrm{BB}$ & 0.000 & & \\
\hline & & AA & 0.583 . & $\mathrm{A}$ & 0.792 \\
\hline & Female & $\mathrm{AB}$ & 0.417 & $\mathrm{~B}$ & 0.208 \\
\hline & & $\mathrm{BB}$ & 0.000 & & \\
\hline Transferrin & & AA & 0.111 & $\mathrm{~A}$ & 0.458 \\
\hline
\end{tabular}




\begin{tabular}{|l|l|l|l|l|l|}
\hline Locus & Sex & Genotype & Observed & Gene & Frequency \\
\hline & Male & AB & 0.778 & B & 0.542 \\
\hline & & BB & 0111 & & \\
\hline & Female & AA & 0.416 & A & 0.458 \\
\hline & & AB & 0.983 & B & 0.542 \\
\hline & & BB & 0.500 & & \\
\hline
\end{tabular}

\section{DISCUSSION}

\section{Gene and Genotype Frequencies Distribution}

The observed Albumin genotypes $\left(\mathrm{Alb}^{\mathrm{AA}}\right.$, $\mathrm{Alb}^{\mathrm{AB}}$ and $\mathrm{Alb}^{\mathrm{BB}}$ ) controlled by codominant alleles $\mathrm{Alb}^{\mathrm{A}}$ and $\mathrm{Alb}^{\mathrm{B}}$ in this study agrees with the report of Fatai et al., [7] for Nigerian indigenous turkey populations of the South West. Polymorphisms at albumin locus have been variously reported in several poultry species. Esmailkahanian et al., [8] observed the albumin genotypes $\mathrm{Alb}^{\mathrm{AA}}, \mathrm{Alb}^{\mathrm{AB}}$ and $\mathrm{Alb}^{\mathrm{BB}}$ in Iranian native poultry breed. Johari et al., [9] also reported the presence of two alleles, A and B in Kedu chickens. Other species such as the Muscovy and Pekin ducks $[10,7]$ have also been reported to exhibit albumin polymorphism. The high prevalence of $\mathrm{Alb}^{\mathrm{AB}}$ among the studied populations may probably suggest adaptive role of the genotype to the prevailing environmental conditions in the study area. Two Haemoglobin genotypes $\mathrm{Hb}^{\mathrm{AA}}$ and $\mathrm{Hb}^{\mathrm{AB}}$ reported in this study are consistent with those reported in Nigerian indigenous turkey populations of South West Nigeria by Fatai et al., [7]. Similar results were reported by Al-Sammarrae et al., [11], Yakubu and Aya [12], Ajayi et al., [13] and Ige et al., [14] in chickens. Birds that are with genotypes $\mathrm{Hb}^{\mathrm{AA}}$ are said to have sufficient oxygen in their blood due to high affinity for oxygen intake while those with $\mathrm{Hb}^{\mathrm{AB}}$ were reported to have insufficient oxygen in blood because of less oxygen intake [15].

The high preponderance of allele A observed at the Haemoglobin locus in this study is not consistent with the findings of Fatai et al., [7] who reported higher frequency of allele $B$ at this locus. This can be explained by the fact that the birds for this study were sourced from a different region (north central) of the country and may suggest an adaptive significance. Moreover, Yakubu and Aya [12] reported the preponderance of allele $\mathrm{A}$ at this locus in the Nigerian indigenous chicken.

Transferrin polymorphism has also been reported in other poultry species, like chickens $[9,16]$ and ducks $[17,10,18]$. The $\mathrm{Tf}^{\mathrm{AB}}$ predominated at the transferrin locus. The effect of heterozygous transferrin appears to have a biological functional effect on egg production, fertility and hatchability (at 90 days of production). Birds with $\mathrm{Tf}^{\mathrm{AA}}$ appear to have delayed sexual maturity while those with the $\mathrm{Tf}^{\mathrm{BB}}$ have earlier age at sexual maturity [15]. The prevalence of allele B at the transferrin locus probably suggests importance of this allele to the birds' survival and adaptation to the study area.
Sex Differences in Blood Protein Polymorphism and Genetic Variability in Indigenous Turkeys

There are scare information in the literature on association of sex with blood protein polymorphism and genetic diversity estimated from blood protein markers in indigenous turkeys to compare or validate the result of the present study. At Alb locus, predominance of genes A and B in both sexes indicated the possibility of sex related physiological advantages that these genes confer on each sex. However, disparities observed in distribution of these protein markers are subject to confirmation with large samples and or studies conducted in controlled environment. At the haemoglobin locus, the higher frequencies of $\mathrm{Hb}^{\mathrm{AA}}$ genotype in both male and female turkey in the present study were in agreement with the reports of Yakubu and Aya [12] on male and female Nigerian local chickens and those of Oguntunji and Ayorinde [19] on indigenous Muscovy duck in Nigeria but contrasted with the report of Salako and Ige [20] on Nigerian indigenous chickens where heterozygous males and females predominated. The prevalence of $\mathrm{Hb}^{\mathrm{A}}$ gene in male and female turkeys is in tandem with reports on Nigerian Local chickens [20, 12]. The high frequency of $\mathrm{Hb}^{\mathrm{A}}$ in the two sexes of Nigerian indigenous turkeys is a pointer to the absence of sex influence on its expression. At the transferrin locus, the prevalence of genotype $\mathrm{Tf}^{\mathrm{AB}}$ in the two sexes coupled with higher frequency of gene $\mathrm{Tf}^{\mathrm{B}}$ is a clear indication of the importance of the gene in the population under study. Besides, similarities in the distribution of the genes in the two sexes indicate that sex has no influence on the expression of the transferrin genotypes and alleles. The report of this study is in consonance with the report of Oguntunji and Ayorinde [19] on Muscovy duck.

\section{CONCLUSION}

The similarities in the allelic and genotypic frequencies at the three blood proteins loci of the turkey indicated that the populations are under similar evolutionary forces. The value of the estimated genetic variability indicated that the two populations are variable in their genome and that there are chances of genetic improvement when crossed between themselves across location or with exotic breeds. The observed uniqueness/distinctness of the turkey should be preserved through such conservative measures as in-situ and ex-situ conservation techniques.

\section{REFERENCES}

1. Olowofeso, O., Wang, J. Y., Dai, G. J., Yang, Y., Mekki, D. M., \& Musa, H. H. (2005). 
Measurement of genetic parameters within and between Haimen chicken populationusing microsatellite markers. International Journal of Poultry Science, 4:143-148.

2. FAOSTAT. (2007). Food and Agricultural Organization statistical databases. CDROM.

3. Arora, R., Bhatia, S., Mishra, B. P., \& Joshi, B. K. (2011). Population Structure in Indian sheep Ascertained using Microsatellite Information. Animal Genetics, 42: 242-250.

4. Salako, A.E., Ijadunola, T. O., \& Aregbesola, Y. O. (2007). Haemoglobin Polymorphism in Nigerian Indigenous Small Ruminant Populations - Preliminary Investigation. African Journal of Biotechnology, 6(22): 2636-2638.

5. RIKEN. (2006). Genetic Quality Monitoring by Biochemical Iso-enzymes. Riken Bioresource Center. Available at, $7^{\text {th }}$ September, 2006.

6. Akinyemi, M. O., \& Salako, A. E. (2012). Genetic Relationship among Nigerian Indigenous Sheep Population using Blood Protein Polymorphism. Agricultural Science and Technology, 4(2):107112.

7. Fatai, R. B., Akinyemi, M., \& Osamede, O. (2017). Genetic Variation in Indigenous Turkey Populations in South West Nigeria. Journal of Advance Animal Research, (7):234

8. Esmaeilkhanian, S. A., Mirhady, R., \& Osfori, P. H. (2000). Genetic Polymorphism in Iranian native poultry breeds part III Albumin and Transferrin polymorphisms. Acta Agraria Kaposvariensis, (4):21-26.

9. Johari, S., Kurnianto, E., \& Hasviara, E. (2008). Blood Protein Polymorphism of Kedu Chicken. Journal Pengembangan Peternakan Tropics; 33(4), 313-318.

10. Johari, S., Ekasari, S., \& Kurnianto, E. (2012). Genetic Variation in three Breeds of Indonesian Local Ducks Based on Blood and Egg White Protein Polymorphism. Journal of Indonesia Tropical Animal and Agriculture; 38(1)20-26.

11. Al-Samarrae, S. H., Al-Bayati, A. J., \& AlMurrani, W. K. (2010). Haemoglobin Polymorphism in Different Animal Species in Iraq. Al-Anbar Journal of Veterinary Science. 3(2), 73-77.
12. Yakubu, A., \& Aya, V. E. (2012): Analysis of Genetic Variation in Normal Feathered, Naked Neck and Fulani-ecotype Nigeria Indigenous Chickens based on Haemoglobin Polymorphism. Biotechnology in Animal Husbandry, 28(2), 377384.

13. Ajayi, F. O., Agaviezor, B. O. \& Wihioka S. N. (2013). Haemoglobin Genotypes in the Nigerian Indigenous Chicken in the Niger Delta Region of Nigeria. International Journal of Advanced Biological Research, 3(1): 13-16

14. Ige, A. O., Salako, A. E., Ojedapo, L. O., \& Adedeji, T. A. (2013). Biochemical Characterization of Indigenous Fulani and Yoruba Ecotypes Chicken of Nigeria. African Journal of Biotechnology, 12(50), 7002-7008.

15. Das, A.K. and Deb, R. (2008). Biochemical polymorphism and its relation with some traits of importance in poultry. Veterinary World, 1(7): 220-222.

16. Guney, O., Ozuyanik, O., Torun, M., Gorgulu \& Darcan, N. (2003). Relationship between Some Polymorphic Parameters and Performances in Damascus goats. Pakistans. Journal Biology Science. 6: 738-740.

17. Zhang, X. F. C., Leung, D. K, Chan, O., \& Yang, G. W. U. (2002). Genetic Diversity of Chinese native chicken breeds based in protein polymorphism, Randomly Amplified polymorphic DNA, and Microsatellite polymorphism. Poultry Science, 81:1463-1472.

18. Oguntunji, A. O., \& Ayorinde, K. L. (2014). Multivariate Analysis of Morphological Traits of the Nigerian Muscovy Ducks (Cairina Moschata) Análisis Multivariante De Caracteres Morfológicos De Patos Muscovy Nigerianos (Cairina Moschata). Archeal Zootechnolog.; 63 (243): 483-493.

19. Oguntunji, A. O., \& Ayorinde, K. L. (2015). Blood Protein Polymorphism and Genetic Diversity in Locally Adapted Muscovy Duck (Cairina moschata) in Nigeria. Animal Genetic Resources, 56:9- 18.

20. Salako, A. E., \& Ige, A. O. (2006). Haemoglobin polymorphisms in the Nigerian Indigenous chickens. Journal of Animal and Veterinary Advances, 5(11), 897-899.

Cite This Article: Ubu I et al (2021). Biochemical Characterization of the Indigenous Turkey (Meleagris Gallopavo) Populations in the Southern Guinea Savannah Of Nigeria Using Blood Protein Markers. EAS J Biotechnol Genet, 3(2), 53-57. 